\title{
Sports at Play in American Politics
}

\author{
Jonathan Shen ${ }^{1}$ and Courtenay Shrimpton"
}

\author{
${ }^{1}$ St. Andrew's College, Aurora, ON, CA \\ \#Advisor
}

ABSTRACT

Sports have been a vital element to American entertainment for decades, which are only gaining popularity. Various sport events allow Americans to temporarily escape the stress associated with their social lives and the divisiveness of partisan politics; however, a closer look at the numerous features of sport games reveal an intricate connection between American sports and politics. With the mandatory playing of the national anthem and the integration of sports and political terminology, sport games in America have become a platform to impose various political ideals. This paper will first introduce how the usage of sport terminologies in politics can simplify a complex process into a game of "winners and losers," which can further political polarization and disincentivize bipartisan collaboration. It will then aim to demonstrate how the imposition of novel rituals that stem from nationalistic and militaristic values can silent dissenting opinions and enforce a homogenous yet unjustified "American Identity." However, the final part of this paper aims to showcase the alternate impacts that sports can have on politics, especially in the realm of sportsdriven activism. This paper does not aim to take a stance on the exact impact that sports can have on American politics, as it is mostly likely to be multi-dimensional, but to unveil to the reader how sports, an entity that is seemingly designed as a form of escape from political agendas, can in reality have substantial impacts on America's political atmosphere.

\section{Introduction}

When reflecting on the nature of American politics, one is likely to recall democratic elections, fiery debates, and civil rights and liberties. At first glance, one is unlikely to associate U.S. politics with sports, and this is unfortunate, as a subtle, elaborate network connects the parallel narratives of American sports and politics. From the customary performance of the national anthem to the flying of the national flags and even military regalia at sporting events, the integration of political and sport rituals is easy to overlook. Sport has become such an abundant source of nationalism, in fact, that George Orwell (1950) once noted that sport is like "war minus the shooting" (pg. 153). This paper aims to examine the counter position between sports' precarious effects on American politics and their potential power to instigate progressive social change. To analyze this juxtaposition, this paper will examine academic research on the prevalence of sports metaphors in political media, the exploitation of sporting events as political propaganda, and an investigation of historical and present political resistance in the realm of sports.

While politics is often an earnest element of American identity, the pervasiveness of sport metaphors in politics has rendered it into a mere game of winners and losers. American media often uses sports terminology to describe and measure politicians' campaigns. For example, during the 2012 presidential election where the entire nation was attentive to the progress of Barack Obama and Mitt Romney, the media was inundated with sport terminologies such as "the bottom of the ninth," "the knockout punch," or "hit a home run" (Bryant, 2012). In fact, these terminologies and the idea of "winning and losing" are so embedded in the language of politics that the masses barely notice them (Stewart, 2013).

This phenomenon of framing elections as games of "winning and losing" can be detrimental to political integrity. American democracy is founded on the free flow of ideas, which John Stuart Mill (1869) argues that a "complete liberty of contradicting and disproving our opinion, is the very condition which justifies us in assuming its 
truth for purposes of action; and on no other terms can a being with human faculties have any rational assurance of being right" (pg. 38), meaning that free competition of ideas optimizes the likelihood of separating the truth from falsehood. However, the portrayal of political duty through the lens of sports diverts the public's focus away from the exchange of ideas between politicians and citizens, ignoring the true purpose of the First Amendment. Instead, citizens are only concerned about the trends of politicians in polls, focusing on who will "win the race" instead of one's actual imprint on the preservation of American democracy (Vieth, 2015). Moreover, the stubborn focus on "winning and losing" worsens the trend of political polarization, which uniquely exacerbates the existing political gridlock as one party blocks legislation solely to prevent the other side's victory (Jones, 2001). Specifically, research finds that in 2016, legislative productivity reached its lowest point in recent US history, where the percentage of bills passed was at a mere 3\%. Worse still, the productivity is projected to experience a further decline in the future (Campbell, 2019). The interference of sports metaphors particularly compounds these issues because their usage has allowed politicians to call for a specific type of fanbase - one that is confined to the ideologies of sports where fanship is measured by a set of allegiance for one's political party's victory, resulting in the refusal to compromise on issues (Bineham, 1991).

Furthermore, not only does the use of sports metaphors exacerbate political deadlock within legislative bodies, it also prevents discussion of public interests among the citizens. In sports, the effects of live spectators are limited to obnoxious cheering as a form of distraction, but in general they have minimal control over the games' results. In contrast, as discussed previously, uncensored debate on political ideals among voters is vital to the prosperity of American democracy. Consequently, the very design and function of America's political system is fundamentally based on citizens' active participation. However, when the media unceasingly illustrate politics as merely a game, it subconsciously implies to the public that they are simply spectators, not active participants (Stewart, 2013). Even when voters have the perception of participation, they are only cheering and hoping for the victory of their party in reality. This is partially evidenced by the fact that only $36 \%$ of Americans can name the three branches of the federal government - the executive, legislative, and judicial (Annenberg Public Policy Center, 2014). Uninformed voters often fail to realize that they are perpetuating the narrative of politics being a game by using the same sport terminologies that the media use, worsening the discord between opposing parties (Pirsl, 2017). Thus, it is imperative for the public sphere to recognize politics as an entity that is greater than just a game, as the notion of “winning and losing” significantly undermines every individual's responsibility in America's democracy.

On top of the "winning and losing" notion that sports metaphors engenders in politics, politicians often exploit sport's emphasis on the "us versus them" narrative (Jhally, 1989). And as with the idea of "winning and losing," the "us versus them" mentality may prove to be calamitous to America's democracy. America is often deemed as a multicultural society where it prides itself for celebrating diverse ethnic and cultural values. However, the narrative of "us versus them" in today's politics, which originates itself in the sport-media complex, has established a conformed support of American sports, such as football and baseball, as a standard of American identity (Jhally, 1989). Rowe (2013) furthers this analysis by arguing that the media has leveraged the widespread popularity of American sports as a form of cultural imperialism, corroding the diverse social dynamics within the borders. This use of American sports and political propaganda reached its peak ensuing the 9/11 attack.

Although Brown (2004) indicates that the existence of sports can serve as messages of a unified America after its injury, he also points out that the emphasis on the omnipresent military imagery bears the risks of associating sports with war. Specifically, the consternation from the terrorist attack of 9/11 induced an environment in which democracy was blunted. This unprecedented atmosphere saw the rise of new waves of patriotic ardor and political conformity (Ivie, 2002). This can be seen in the replacement of "Take Me Out to the Ball Game" by a new ritual during the seventh inning - the imposition of the mandatory performance of "God Bless America." Since it was commonly performed by the U.S Armed Forces, the song not only eliminated the nostalgic sentiment of "Take Me Out to the Ball Game," but also foisted an element of nationalism and militarism. Butterworth (2005) reinforces Brown's warning by finding that "ballpark rituals... evolved quickly into expressions of American nationalism and hegemony" (pg. 123). He further argues that implementation of new baseball rituals rooted in a one-dimensional militaristic and nationalistic identity solidifies the perceived existence of a foreign threat, giving reason to "de- 
legitimized dissenting opinions" in the name of national security (Butterworth, 2005). Therefore, these scholars have highlighted that sports have served as a form of political rhetoric that coerces a unified American identity in times of crisis.

Granted that the incorporation of sports metaphors and terminologies within politics can have concerning effects on the validity of American democracy, the emerging wave of political resistance in the realm of sports may have initiated systemic changes in social justice issues. Just as how sports can be used as a political strategy to conform ideals due to its widespread popularity, this same mechanism means that when it is used as a platform that proactively resists the dominant ideology, it can become a site for productive political debate and social change. The earliest form of resistance in sports can be seen by activist athletes during the Civil Rights Movement. During the 1960s, the nation saw boxing legend Muhammad Ali using his status and platform to resist racism and war. Refusing to be drafted into the U.S. military and citing his opposition against the Vietnam War, Ali was punished with a three-year suspension of his boxing license. Ali's defiance against the U.S. government embodied the rhetoric in social movements that invoke the paradox of violence in nonviolent civil disobedience. Utilizing the physical impacts of his dominance in a violent sport, Ali aimed to showcase the importance of nonviolence on the global stage (Gorsevski \& Butterworth, 2011). Ali's actions were then followed by one of the most symbolic moments in sports history.

During the 1968 Olympics in Mexico City, Tommie Smith and John Carlos bowed their heads and raised their fists clad in black gloves - the salute of Black Power - on the podium after winning gold and bronze medals in the 200-meter sprint. Effectively, Smith and Carlos, two of America's greatest athletes at the time, sacrificed their glory to protest the systemic racial inequality in their home country (their actions resulted in them being dismissed from the Olympics) (Younge, 2012). Despite the act's brevity, it "created a moment of resistance and confrontation with dominant and existing forms of racial identity" (Bass, 2002, pg. 239). Thus, in the midst of political turmoil during the 1960s and 70s, athletes such as Mohammad Ali, John Carlos, and Tommie Smith were able to use their success in sports as a platform to advocate and advance social movements such as the Civil Rights Movement and Vietnam War protests.

Following the end of the Civil Rights Movement, however, the nation saw a decline in activist athletes due to the burgeoning of athletes' income and status in the capitalistic nation. With their diminishing privacy, athletes started to protect themselves by sustaining a positive public perception by conforming to political norms, since it was the only way to attract endorsement and appease capitalistic organizations (Lipstye, 2002). Despite the declining trend of initiating political resistance, athletes sometimes still feel compelled to express their political stance, especially in the $21^{\text {st }}$ century. In 2004, Carlos Delgado of the MLB refused to participate in the performance of the "God Bless America" ritual. In 2013, Dwayne Wade of the NBA was headlined in the Ebony cover with his sons wearing hoodies, continuing the protest against the murder of African American teen Trayvon Martin in Florida and the acquittal of his killer George Zimmerman (Billings, 2017). Throughout her career, Serena Williams defies the constraints of what "black excellence" should be. Instead, she embraces her identity in the face of prejudice and displays her emotions regardless of opposition from the white majority (Rankine, 2015).

With recent rising reports of police brutality against minority groups and other actions that reflect the persistent systemic racism in the United States, the public is witnessing a resurgence of political resistance in the sports world. In 2017, the silent action of taking a kneel during the National Anthem as a form of protest against police brutality by the former San Francisco 76ers quarterback Colin Kaepernick led to the one of the most divided complexes in popular culture's history. With the political nature behind his action, Kaepernick has parted the public and the elites into polarizing groups, with one viewing him as a traitor of the country and the other seeing him as a hero (Branch, 2017). What differentiates Kaepernick's action from the other acts of protest in the $21^{\text {st }}$ century is the parallel backlash that he faced when compared to those in the 1960s. Unlike Carlos Delgado or Dwayne Wade, who did not jeopardize their career with their actions, every team in the National Football League (NFL) has refused to sign Kaepernick since his 2017 season.

Though partisan politics and emotional debates surrounding racial inequality and patriotic rituals subdued transiently, the murder of George Floyd by a police officer in May of 2020 sparked a new wave of the Black Lives 
Matter (BLM) movement, including the participation of major sports organizations. With $80 \%$ of the National Basketball Association (NBA) and 70\% of the NFL being people of color (Tower, 2018), these sports organizations bear a unique role in the emerging movement of BLM (Nweke, 2020). Specifically, the NBA has dedicated its remaining season in the "bubble" to the BLM movement. Moreover, multiple teams in the NBA chose to boycott their games following the death of Jacob Blake, another African American man who was shot by a police officer in Wisconsin. The NFL has shifted away from its negative outlook of protests in 2017 and released a video of commissioner Roger Goodell condemning racism (Moradi, 2020). The question of whether or not these sports driven protests will lead to systematic changes in state legislatures cannot be answered at this moment; nonetheless, just as the popularity of sports can shift the public's perception of politics negatively, activism that stems from athletes and sports organizations can have positive impacts on social issues.

While the existence of sports in American politics is an indisputable status quo, this status quo can both nullify and advance the democratic ideals of America. On the one hand, academic scholars such as David Jones and Michael Butterworth are weary of the emerging detriments of the "winning and losing" and "the us versus them" notions on America's democracy. On the other hand, recent trends such as the Black Lives Matter movement that is driven by the participation of athletes and sport organizations demonstrate the possibility of sport-incited political and social progression. Through this paper, it is evident that abundant research exists to indicate that both facets can coexist, yet which side will prevail at the end is still unclear.

\section{Acknowledgments}

This research paper would not have succeeded without the help of others. The author would first like to thank Mr. Shrimpton for assisting in the organization and structure of the research paper. The author would also like to thank Bryan Weber for his guidance in the research process, teaching the author the skills of evaluating evidence and effectively applying them to the paper's claims. Additionally, the author needs to thank his peers in editing his paper and pinpointing grammar mistakes. Lastly, the author would like to acknowledge the generous support of St. Andrew's College. All errors and omissions remain the author's.

\section{References}

The Annenberg Public Policy Center of the University of Pennsylvania. (2014, September 17). Americans know surprisingly little about their government, survey finds. The Annenberg Public Policy Center of the University of Pennsylvania. https://www.annenbergpublicpolicycenter.org/americans-know-surprisinglylittle-about-their-government-survey-finds/.

Bass, A., \& Bass, A. (2002). "That's My Flag". In Not the triumph but the struggle: the 1968 Olympics and the making of the Black athlete (Ser. Critical American Studies, pp. 233-290). essay, University of Minnesota Press. https://www-jstororg.libproxy2.usc.edu/stable/pdf/10.5749/j.ctttv4xf.11.pdf?refreqid=excelsior\%3A711bd68ecffd4792bced3 $847 \mathrm{c} 0 \mathrm{e} 8517 \mathrm{e}$.

Billings, A. C., Butterworth, M. L., \& Turman, P. D. (2017). Politics and Nationalism in Sport. In Communication and sport: surveying the field (pp. 161-186). essay, Sage. https://us.sagepub.com/enus/nam/communication-and-sport/book245878\#contents.

Bineham, J. L. (1991). Some ethical implications of team sports metaphors in politics. Communication Reports, 4(1), 35-42. https://doi.org/10.1080/08934219109367519

Branch, J. (2017, September 7). The Awakening of Colin Kaepernick. The New York Times. https://www.nytimes.com/2017/09/07/sports/colin-kaepernick-nfl-protests.html.

Brown, R. S. (2004). Sport and healing America. Society, 42(1), 37-41. https://doi.org/10.1007/bf02687298 
Bryant, N. (2012, September 27). The shared language of sport and politics. BBC News. https://www.bbc.com/news/magazine-19726898.

Butterworth, M. L. (2005). Ritual in the "Church of Baseball": Suppressing the Discourse of Democracy after 9/11. Communication and Critical/Cultural Studies, 2(2), 107-129. https://doi.org/10.1080/14791420500082635

Campbell, J. A. (2019). Political Gridlock: The Ongoing Threat to American Democracy. Gettysburg Social Sciences Review Fall 2019, 3(2), 4-41. https://cupola.gettysburg.edu/cgi/viewcontent.cgi?article=1059\& context=gssr.

Gorsevski, E. W., \& Butterworth, M. L. (2011). Muhammad Ali's Fighting Words: The Paradox of Violence in Nonviolent Rhetoric. Quarterly Journal of Speech, 97(1), 50-73. https://doi.org/10.1080/00335630.2010.536563

Ivie, R. L. (2002). Rhetorical Deliberation and Democratic Politics in the Here and Now. Rhetoric \& Public Affairs, 5(2), 277-285. https://doi.org/10.1353/rap.2002.0033

Jhally, S. (1984). The Spectacle of Accumulation: Material and Cultural Factors in the Evolution of the Sports/Media Complex. Insurgent Sociologist, 12(3), 41-57. https://doi.org/10.1177/089692058401200304

Jones, D. R. (2001). Party Polarization and Legislative Gridlock. Political Research Quarterly, 54(1), 125-141. https://doi.org/10.2307/449211

Lovinger, J., \& Lipsyte, R. (2002). Prophets. In The Gospel According to ESPN: Saints, Saviors \& Sinners (First, pp. 9-58). essay, Hyperion.

Mill, J. S. (1869). Chapter 2. In On Liberty (Fourth, pp. 38-38). essay, London: Longmans, Green, Reader and Dyer.

Moradi, E. (2020, September 7). 'Generation Kaepernick': Activist-athletes uplift voices for justice. Berkeley News. https://news.berkeley.edu/2020/08/28/generation-kaepernick-activist-athletes-uplift-voices-for-justice/.

Nweke, O. N. (2020, October 13). How have sports shaped the Black Lives Matter movement? Public Interest Media. https://www.thebigq.org/2020/10/13/how-have-sports-shaped-the-black-lives-matter-movement/.

Orwell, G. (1950). The Sporting Spirit. In Shooting an Elephant: and other essays (pp. 151-155). essay, Reclam.

Piršl, D., Petković, E., Dragić, B., \& Piršl, T. (2017). Sports Metaphors Make Political Discourse More Punching. Proceedings of The 5th Virtual Multidisciplinary Conference, 124-127. https://doi.org/10.18638/quaesti.2017.5.1.321

Rankine, C. (2015, August 25). The Meaning of Serena Williams. The New York Times. https://www.nytimes.com/2015/08/30/magazine/the-meaning-of-serena-williams.html.

Rowe, D. (2013). The Sport/Media Complex. A Companion to Sport, 61-77. https://doi.org/10.1002/9781118325261.ch3

Stewart, D. (2013, May 3). It's time to stop treating politics as a sport. The Week. https://theweek.com/articles/464757/time-stop-treating-politics-sport.

Tower, N. (2020, November 12). In an ethnic breakdown of sports, NBA takes lead for most diverse. Global Sport Matters. https://globalsportmatters.com/culture/2018/12/12/in-an-ethnic-breakdown-of-sports-nba-takeslead-for-most-diverse/.

Vieth, D. (2015). The Impact of Sports Metaphors on the Media and Public Sphere. Lexia: Undergraduate Journal in Writing, Rhetoric \& Technical Communication, 3. https://commons.lib.jmu.edu/cgi/viewcontent.cgi?article=1020\&context=lexia.

Younge, G. (2012, March 30). The man who raised a black power salute at the 1968 Olympic Games. The Guardian. https://www.theguardian.com/world/2012/mar/30/black-power-salute-1968-olympics. 